\title{
行動則の獲得状況を考慮した自己組織化 マップによる状態空間構成法
}

\author{
斎藤 史哲 $* 1 \cdot$ 長谷川 修 $* 2$
}

\begin{abstract}
強化学習エージェントの状態空間構成に自己組織化マップ（Self-Organizing Map：SOM）などの競合 学習を行うニューラルネットを用いる方法が近年多く報告されている。これらの方法では強化学習器に $\mathrm{Q}$ - learningなどの環境同定型の強化学習を用いることが前提とされており, Profit Sharingにおける状態空 間構成にSOMを使用したときは行動規則の学習の速さをSOMの学習が追従できない. そこで本研究では, SOM を Profit Sharingによる強化学習エージェントの状態空間構成に利用した場合においても，SOMが Profit Sharingの学習の速さを追従可能とするための “相互学習残参照型近傍関数”を提案し, その有効性 をシミュレーションタスクでの実験により示す.
\end{abstract}

キーワード：自己組織化マップ, 強化学習, Profit Sharing, 近傍関数, 状態空間構成

\section{1. はじめに}

\section{1 研究背景}

近年, 強化学習は知能ロボットなどの自律エージェ ントの行動獲得手段として注目されている。強化学習 は試行錯誤を通じて環境から与えられる報酬に基づき 環境からの知覚入力に対する適切な行動出力を学習す る枠組みであり，それを実現するためにQ-learningや Profit Sharingなどのアルゴリズムが提案されてい る.これらのアルゴリズムの多くは知覚入力に対する 状態空間が離散化された有限集合として定義されてい るため, 知覚入力が連続值として与えられる実環境に おけるタスクなどに適用しようとするときには, 予め 何らかの方法で知覚入力の離散化が施される。しか し, 次の理由[Moore95]から複雑かつ大規模なシステ ムにおいては設計者がこの離散化を適切に行うことは 必ずしも容易ではない。

・もし微細な離散化を行ったとするとより適切な行 動則が獲得しやすくなる反面, 探索空間が爆発し 実時間での学習が困難となる。

・逆に粗く離散化を行うと, 状態数が少なく済むた

$\dagger \quad$ State Space Construction Method with Self- organizing Map in a Reinforcement Learning System Based on Profit Sharing Fumiaki SAITOH and Osamu HASEGAWA

*1 東京工業大学大学院総合理工学研究科知能システム科学専攻 Department of Computational Intelligence and Systems Science Interdisciplinary Graduate School of Science and Engineering, Tokyo Institute of Technology

*2 東京工業大学大学院理工学研究科像情報工学研究施設 Imaging Science and Engineering Laboratory, Tokyo Institute of Technology

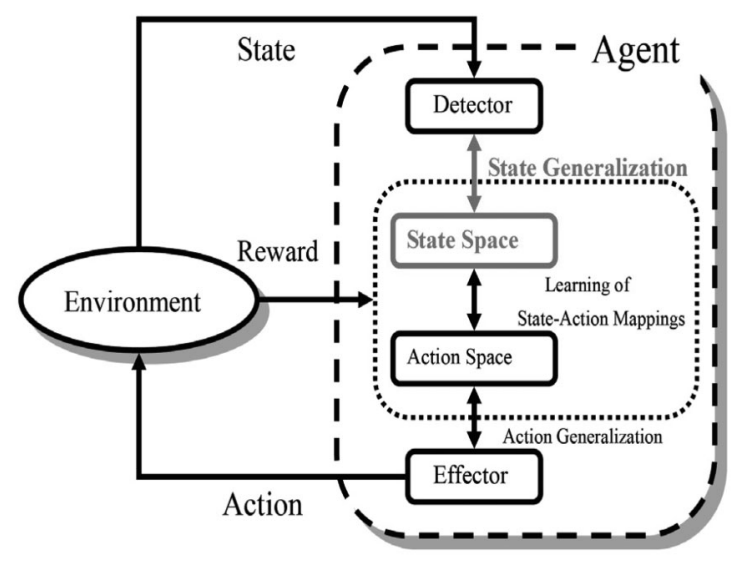

図 1 エージェントの構成

め試行錯誤数は少なく済むが，本来区別されるべ き状態を同一視してしまう『不完全知覚問題』が生 じ，適切な学習が行われなくなってしまう。

そこで，この離散化をいかに行うかが獲得する行動 則の質や学習速度に大きく影響を及ぼすと考えられて 打り，エージェント自身が適切に内部状態空間構成を 行う方法に関する研究が重要視されるようになってき ている [Asada96, Yairi00, Albus95, McCallum95].

\section{2 強化学習器の分類}

一般に, 強化学習の学習器はQ-learning (以下QL) などの環境同定型の学習と, Profit Sharing(以下PS) などの経験強化型の学習に類別されている[山村95]. 強化学習を工学に応用する際に必要であると考えられ 
る要件として『適用可能なクラスが広いこと』と『素早 い学習が可能であること』が挙げられるが，QLなどの 学習器はこれらの要件を満たしていない，それに対し て, PSは部分観測マルコフ決定過程 (Partially Observable Markov Decision Processes : POMDPs)の 環境下でも学習性能を発揮でき, 学習の立ち上がりが 速いことからこれらの要件を満たしていると言われて いる。このことから PSは実タスクへの応用が期待さ れている。[宮崎99］

\section{3 自己組織化マップによる状態空間構成}

近年, 状態空間構成に関する研究では自己組織化 マップ (Self-Organizing Map：SOM) [Kohonen90]な どの競合学習型のニューラルネットワークを用いて状 態空間構成を行うアプローチ $[$ Smith02, 半田04, 岩 崎05]が提案されている.SOMは緩やかな環境の変化 への追従が可能であることや, 知覚入力保持のための 膨大なメモリを必要としないこと, 多次元で連続值の 知覚入力分布から離散空間への写像が容易に得られる ことなどが利点とされている。

SOMなどを用いて状態空間構成を行う先行研究で は, 利用される強化学習器としてQLなどの環境同定 型の強化学習を用いることが前提とされている。こ れは，QLでは報酬が徐々に周囲の状態に伝搬してい く形で学習が進行するため行動則の獲得が非常に遅い ことから，行動則を獲得している間にSOMの学習を 適切に行えるためと考えられる。

一方，PSの状態空間構成にSOMを利用した場合は 行動則の獲得が速いことから, PSの学習速度にSOM による状態空間構成が追いつかない，そのため，学習 初期の状態空間で獲得した行動則とその後の状態空間 で獲得した行動則の間にズレが生じてしまい，行動則 の獲得がうまく進まなくなってしまう。

このことから，PSを利用する前提でSOMのような 競合学習型ニューラルネットを用いて状態空間構成を 行うことに関する十分な議論はなされていない.

そこで本研究では，SOMによる状態空間構成がPS による行動則の獲得をスムーズに追従できるようにす るための “相互学習残参照型近傍関数”を提案し，これ を用いたSOMで状態空間構成を行った場合の有効性 を示す.

以下本稿では，2 章でPSについて概説し，3 章で SOMについて概説する．4 章では本研究で提案する 相互学習残参照型近傍関数について説明する．5章で はシミュレーション実験により本提案の有効性を検証 し，考察する． 6 章で本論文の結論を述べる。

\section{Profit Sharingによるルールの獲得}

本章では，PSによるルールの獲得方法について概 説する．PSは報酬を得たときにエピソード単位で使 用したルール系列を一括的に更新する学習手法であ る.

報酬を得た時点から逆にさかのぼってどれだけ過去 に使用されたルールかによって更新時の強化值を返す 関数を強化関数と呼ぶ.

この強化関数 $f_{i}$ は報酬 $r$ を使用されたルール順に配 分する。ルールの重みは次式によって更新される.

$\omega\left(s_{i}, a_{i}\right) \leftarrow \omega\left(s_{i}, a_{i}\right)+r \times f_{i}$

ここで, $\omega\left(s_{i}, a_{i}\right)$ はエピソード系列において $i$ 番目 のルールの重みを表している。

あるエピソードに打いて同一状態が複数回存在し， それぞれにおいて別の行動を選択しているとき状態遷 移系列にループが生じてしまう。このようなループ上 に存在する行動則を無効ルール，それ以外の行動則を 有効ルールと呼ぶ。合理性定理［宮崎94]では，エピ ソード内に無効ルールが存在するときに無効ルールよ りも有効ルールを大きく更新するための条件式が議論 されている。一般に, 強化関数には合理性定理を満た す以下のような等比減少関数が用いられる。

$f_{n}=\frac{1}{S} f_{n-1} \quad, \quad n=1,2, \cdots, W-1$

$W$ はエピソードの最大長， $1 / S$ は報酬割引率 $(S \geqq$ $L+1)$ を表している。ここで， $L$ は同一感覚入力下に 存在する有効ルール数を表している．Lは一般に学習 前に知ることはできないが，行動出力数より 1 を引い た值で十分であるとされている。

強化関数に等比減少関数を用いた場合, 報酬に近け れば近いほどルールの強化值が大きくなる。これによ り報酬獲得に貢献した有効ルールが貢献していない無 効ルールの働きを抑制できる.

PSにおける行動則の価值は累積值ベースで評価さ れており，報酬に至るまでの経験の度合いを示してい る。そこで，行動選択時はルーレット選択やボルッマ ン選択などの確率的政策を用いることによって，経 験の度合いが大きいルールほど選択されやすくするこ とが一般的である。

QLでは他のルールの価值に基づきルールの価值の 更新を行うので，他のルールの価值が収束しないと更 新対象のルールの価值が収束しない。 それに対して, PSでは他のルールの価值とは独立にルールの価值を 更新するため，他のルールが更新されなくても報酬獲 
得において頻繁に使用されるルールの価值は収束する ことが多く，学習の立ち上がりが早い。その反面，局 所解(準最適解)に陥る可能性があることから獲得した 行動則の最適性は保証されない。しかし, PSは他の 状態の評価值を必要としないため, 完全な状態情報を 得ることができないPOMDPsの環境における学習法 として有効であると考えられている.

\section{3．自己組織化マップ (Self-Organiz- ing Map)}

本章ではSOMについて概説する.SOMは入力層と 出力層(競合層)の 2 層からなるフィードフォワード型 のニューラルネットワークであり, 競合学習を行うこ とで, $n$ 次元の入力データ空間 $X$ から位相関係を保持 したまま離散空間 $A$ を表すマップ上に写像を得ること ができる。

また出力層の各ノードは, $n$ 次元の入力ベクトル $\mathbf{x}=\left[x_{1}, x_{2}, \cdots, x_{n}\right]^{T} \in R^{n}$ と同次元の結合重みべクトル $\mathbf{m}=\left[m_{i 1}, m_{i 2}, \cdots, m_{i n}\right]^{T} \in R^{n}$ を持つ.

出力層では入力ベクトルと結合荷重ベクトルのユー クリッドノルムが最小になるノードを勝者ノードと し，次式によって識別される。

$\left\|x(t)-m_{c}(t)\right\|=\min _{i}\left\|x(t)-m_{i}(t)\right\|$

通常のSOMにおいては図 2 のように, 勝者ノード とその近傍ノードの結合重みべクトルは次式によって 更新される.

$m_{i}(t+1)=m_{i}(t)+\alpha(t) h_{i c}(t)\left[x(t)-m_{i}(t)\right]$

学習率係数 $\alpha(t)(0<\alpha(t)<1)$ は学習の進展に伴い 単調に減少する関数である。また $h_{i c}$ は近傍関数であ り，次式によって表される。

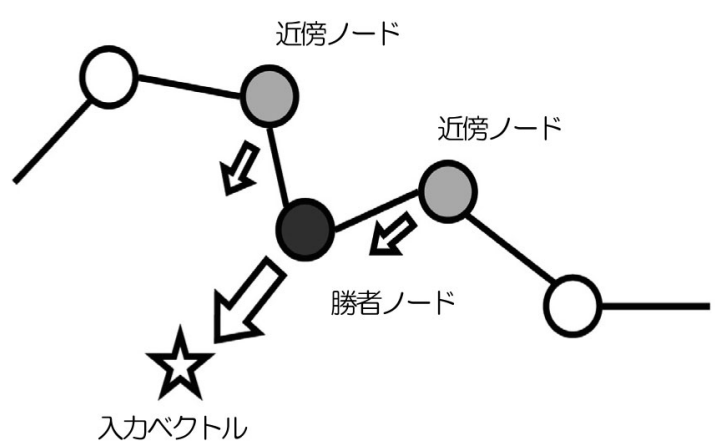

図 2 通常の SOM の近傍ノードの更新

$$
h_{i c}= \begin{cases}1 & (i=c) \\ \exp \left(-\frac{\left\|r_{c}-r_{i}\right\|^{2}}{\sigma(t)^{2}}\right) & \left(i \in N_{c}(t)\right) \\ 0 & \left(i \notin N_{c}(t)\right)\end{cases}
$$

ただし, 近傍の広がり $\sigma(t)$ はパラメータであり単調 に減衰する。 $i=c$ はノード $i$ が勝者になったときを表 しており， $N(t)$ は勝者ノードの近傍ノードの集合を 表している。この近傍関数を用いて更新することに よってマップの位相関係を保持する事ができる。

\section{4. 提案手法}

\section{1 提案手法の方針}

理想的な状態空間を得るためには，1.1で述べた知 覚入力を細かく離散化することと粗く離散化すること の間に生じるトレードオフを解消する必要がある。そ のためには, 知覚入力空間中のタスクの達成において 肝要な領域は不完全知覚に陥らないようにするために 細分化し，適切な行動則を獲得しやすくする必要があ る。逆に，そうでない領域は細分化を避けることに よって無駄な試行錯誤を避けることが望ましい。そこ でタスクの達成において肝要な領域で不完全知覚に 陥っている領域にはより多くのノードを配置する必要 がある。また，SOMを用いた状態空間構成に打いて 適切な行動則を獲得するには, タスクを達成するため に肝要な領域とそうでない領域との間でノードの粗密 の差を明確にしなくてはならない.SOMは入力頻度 の高い領域にはノードが多く配置されノードの密度が 高くなる性質がある。この性質は不完全知覚に陥って いる状態にはエージェントが訪問する頻度が高くなる 傾向が強いことから，その領域のノードの密度が高く なり細分化が進むため, 不完全知覚を回避するために 有効に働く.

しかし, エージェントはタスクの達成において必要 な状態は必ず訪問する。このため, 行動則の獲得が進 行していても訪問する頻度は高くなりノードの密度が 高くなってしまう。行動則の獲得が進行している領域 に必要以上のノードを配置する事は, 行動則の獲得に 打いて無駄な試行錯䛊を要してしまうことを意味す る。そこで, タスクの達成に打いて肝要でかつ不完 全知覚状態に陥っており行動則の獲得が進んでいない 領域にのみ多くのノードを配置し, 不完全知覚状態を 回避する必要がある。

また, SOMの学習初期は勝者ノードに対する近傍 範囲が広く学習率も大きいため, 各ノードの配置は変 化しやすくマップの形状は不安定である。そのため各 
状態を表す領域(ノードの発火域)は非常に変化しやす $く$ ，学習初期に獲得された行動則がその後の各状態を 表す領域において適用可能とは限らない。

以上より，行動則の獲得が進んでいるノードでは無 駄な更新を避け, 知覚入力空間上の発火域の変化を避 けることが望ましい，逆に，行動則の獲得が進行して いない領域に配置されているノードには不完全知覚問 題が生じ，適切な細分化が行われていない可能性が高 いため，発火域を狭くするようにノードの密度を高く する必要がある。

\section{2 行動則獲得状況の評価}

不完全知覚に陥っている状態では区別しなくてはな らない状態を同一視してしまうため，一つの状態に対 して複数の行動則が強化されてしまう。そのため, 不 完全知覚の状態では行動則の重みの差が大きくなりに くく学習が進まない。 そこで, 本研究ではこの不完全 知覚状態の判定を行うために, 行動則の獲得状況を評 価する指標として[伊藤01]で用いられた学習残エント ロピー(式 6 )を利用する。

$I(S)=-\left(\frac{1}{\log |A|}\right) \sum_{a \in A} p(a \mid s) \log p(a \mid s)$

ここでは, 行動選択率 $p(a \mid s)$ は各内部状態 $\mathrm{s}$ で 行動 $a$ を選択する確率であり，Aは行動空間(取りうる 行動の集合)を表し, $|A|$ は可能な行動数を表す。こ の指標は各状態に対する行動の獲得状況を表してお り, 行動の不確定性 (自由度)がどの程度残っているか を評価できる、未学習の状態では各行動の選択確率は 同じ值となるため 1 となるが, 学習が進むにつれて小 さくなり，完全にある特定の行動のみを選択するよう になったときには 0 となる。

以下本稿では, 行うべき行動が確定していて学習残 エントロピーの值が小さな状態を表すノードを『既学 習ノード』, 行動則の獲得が進まず学習残エントロ ピーが大きい状態を表すノードを『未学習ノード』と呼 ぶことにする。

\section{3 相互学習残参照型近傍関数}

勝者ノード(選択された状態)が既学習ノードである 場合，その領域においてそれ以上の細分化を行うこと は適切ではない。そこで, 図 3 のように勝者ノードの 行動則の獲得が進行している場合はその領域の細分化 を抑制するために近傍関数は小さな值を返すようにす ることが望ましい.

逆に, 図4のような行動則の獲得が進んでいない未

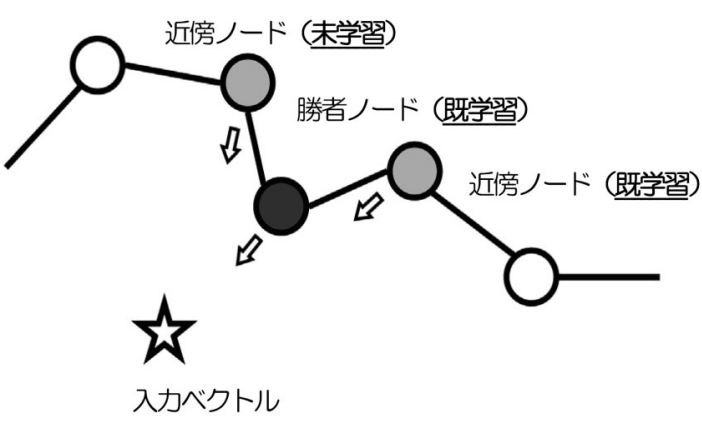

図 3 提案手法における勝者ノードが既学習時の更新

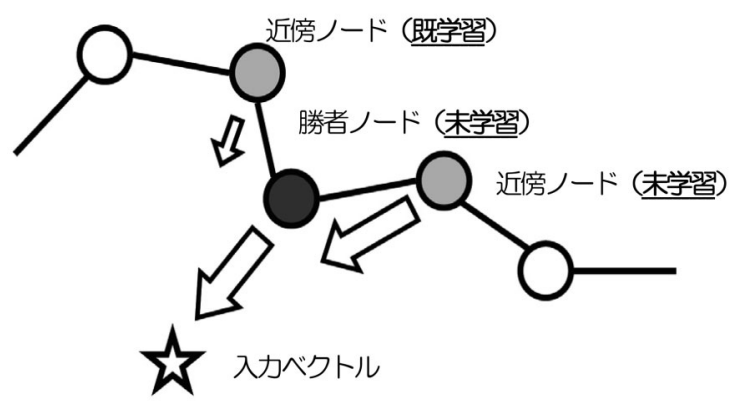

図 4 提案手法における勝者ノードが未学習時の更新

学習ノードの発火域が表す領域では, 不完全知覚状態 に陷っている可能性があるため細分化を促進すること が望ましい. よって近傍関数は大きな值を返すように し, 近傍ノードを勝者ノードに近づける必要がある。 しかし近傍ノードが既学習ノードである場合は, 発火 する領域と選択する行動の整合性を保つためにその近 傍ノードの更新を抑制しなくてはならない。

以上のことを踏まえて本研究では, 行動則の獲得の 進行度に応じて望ましい值を返す近傍関数として『相 互学習残参照型近傍関数』(式 7$)$ を提案する.

$h_{i c}= \begin{cases}I(c)^{2} & (i=c) \\ I(c) I(N) & \left(i \in N_{c}(t)\right) \\ 0 & \left(i \notin N_{c}(t)\right)\end{cases}$

式 7 は, ノード $i$ が勝者になったとき $(i=c)$ の近傍 関数を表している。ここでは， $N_{c}(t)$ は時刻 $t$ におけ る勝者の近傍ノードの集合を表している。また， $I(c)$ は勝者ノードが表す状態の学習残エントロピーであ り, $I(N)$ は近傍のノードが表す状態の学習残エント ロピーである。

この相互学習残参照型近傍関数では勝者ノードの近 
傍関数は勝者ノード自身の状態が獲得している学習残 エントロピーの二乗であり, その近傍は勝者ノードの 学習残エントロピーと更新する近傍ノード自身の学習 残エントロピーの積を用いる. $I(c) I(N)$ を用いて近傍 を更新することにより，勝者ノードが未学習ノードで かつ近傍ノードが未学習ノードである場合にのみ近傍 関数は大きな值を返すようになり発火域が狭くするよ うに働く。それ以外の場合は小さな值を返し更新を抑 制するようになる。

この近傍関数はノードが発火したときにそのノード が持っているルールを用いて更新の度合いを決定す る。

図 3 のように勝者ノードが既学習の場合, 行動の選 択確率に偏りが生じるため $I(c)$ の值は小さくなる．例 えば，選択できる行動が 4 種類の場合で全ての行動選 択確率が $p\left(a_{1} \mid c\right)=0.05, p\left(a_{2} \mid c\right)=0.02, p\left(a_{3} \mid c\right)=$ $0.03, p\left(a_{4} \mid c\right)=0.9$ のように充分学習が進んでいると きは $I(c)=0.3088$ となり, 近傍ノードの学習残エント ロピー $I(N)$ の值によらず近傍の值が小さくなる。

また，図4のように勝者ノードが未学習のときは ノード行動の選択確率に偏りが生じないため, $I(c)$ の 值は大きくなる，例えば，選択できる行動が 4 種類の 場合で学習が進まず全ての行動選択確率が同じときは $p\left(a_{1} \mid c\right)=0.25, p\left(a_{1} \mid c\right)=0.25, p\left(a_{1} \mid c\right)=0.25, p$ $\left(a_{1} \mid c\right)=0.25$ で $I(c)=1$ となり, 近傍ノードの学習 残エントロピー $I(N)$ の大小に応じて近傍の更新值を 変化させることが出来る.

この近傍関数を用いて各ノードの行動則の獲得状況 を評価しながら更新していくことによって，ノードの 配置を自律的に決定することが可能となる。頻繁に勝 者となる領域に未学習ノードと既学習ノードが混在し ているときは, 既学習ノードは必要以上に近傍ノード を引き付けないため，領域間でのノードの奪い合いが 回避でき，適切にノードの配置が確定しやすくなる。 また, 不完全知覚に陥っているため知識 (行動則)の獲 得が進まず，かつタスクの達成において重要な領域に 優先的にノードを配置し，より適切な行動則を獲得し やすくなる。

以上より，提案した近傍関数を用いるだけでエー ジェント自らが知識の獲得が不十分な領域に対して, より詳しく知識を得るよう働きかけ，内部状態空間構 成が出来るようになるとこが期待できる。また，本提 案では状態空間全体を評価する必要は無く，局所的な 行動則の獲得状況を評価するだけでマップ全体がタス クを達成するためにより適した状態空間を構成するよ うになる。

\section{5 . 実験}

\section{1 実験設定}

提案手法の有効性を検証するためにエージェントの ナビゲーションタスク(迷路問題)に打ける計算機シ ミュレーションを行った。

エージェントが置かれる環境は四 5 に示した 2 次元 の $(x, y)$ 平面環境である。位置を表す各座標は 1 から 60の整数值を取るものとする。エージェントは図中の 黒塗りの部分 (外壁打よび障害物)には進入できず，進 入するような行動を行うと強制的に行動をとる前の位 置に戻されるものとする。

このタスクでは, エージェントはゴール地点に到達 したときに報酬を与えられ，スタート地点からゴール 地点までの最短経路を学習する。エージェントの知覚 入力は現在エージェント自身がいる位置座標を二次元 ベクトルの形で入力されるものとする.

行動は『上へ移動, 下へ移動, 左へ移動, 右へ移動』 の中から 1 つ選択されるものとし，各行動でそれぞれ の方向に 1 マス進めるものとする.

実験では

・均一なグリッド状に分割を行った場合（図 6 )

二次元SOMを用いて状態空間構成を行った場合 提案する近傍関数を用いた二次元SOMを用いて 状態空間構成を行った場合

の 3 手法をそれぞれ迷路 1 ，迷路 2 に適用して実験し

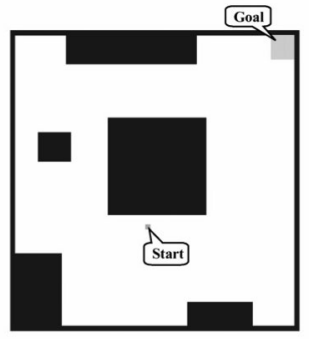

(a) 迷路 1

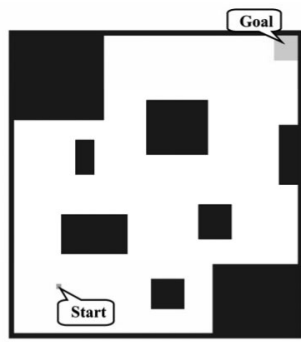

(b) 迷路 2
図 5 想定するタスク

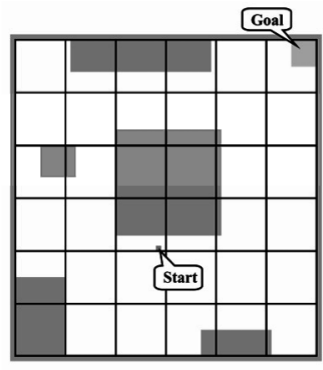

(a) 迷路 1

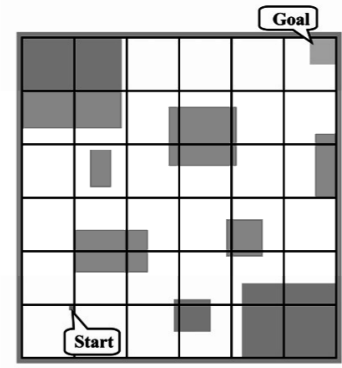

(b) 迷路 2
図 6 グリッド分割を行った場合の状態空間 
表 1 SOM の学習率, 近傍の範囲

\begin{tabular}{c|c}
\hline パラメータ & 值 \\
\hline \hline 学習率係数 & $0.8 \times(0.9995)^{e p i}$ \\
近傍の広がり & $3 \times(0.9995)^{e p i}$ \\
\hline
\end{tabular}

$e p i$ はエピソード数である。ルールの更新時に用い る強化関数には公比 $0.25 の$ 等比減少関数を用いた.

た、いずれの手法に打いても $6 \times 6$ の合計 36 の状態を 識別できるようにし, SOMの形状は二次元格子状と した.

今回の実験の設定として,SOMでは近傍の広がり の初期值は 3 とし, 表 1 のようにエピソード数を重ね るにつれて近傍の広がりを狭めていくような一般的に 利用される近傍のとり方と同様のものとした。学習率 も同様に, 初期值 0.8 か減少していくものとした. 提案手法の近傍ノードは勝者に隣接するノードとし, 学習率は通常のSOMと同じものを用いた. SOMの更 新は各ステップにおいて知覚入力が獲得される毎に行 う。状態識別は各エピソードの知覚入力を保持してお き，エピソード終了後のルールの重み付けを行うとき に，どのノードが発火するかを調べるものとした。各 手法における行動選択にはルーレット選択を用いた。

\section{2 実験結果}

上記の実験環境における実験結果として学習曲線と 獲得された状態空間を示す。この結果より，グリッド 分割や通常のSOMにより状態空間構成をした場合と 提案手法によって状態空間構成をした場合の結果を比 較・検証する。

\subsection{1 学習曲線}

図 7,8 に提案手法, 通常のSOM, グリッド分割 を行った場合の学習曲線を示す。ここでは, 縦軸はタ スクの達成に要したステップ数, 横軸はエピソード数 を表している，学習曲線は，各手法において50試行ず つ行いその各エピソードの平均值をプロットしたもの である。また，曲線を見やすくするために 10 エピソー ド区間で移動平均をとり滑らかにしてある。

図 7 および図 8 より, 通常のSOMPグリッド分割 を行ったものより提案手法の方が, 圧倒的に立ち上が りが早く効率よく行動則を獲得出来ていることがわか る。通常のSOMやグリッド分割を行ったときは，工 ピソードごとのばらつきが大きく，獲得された行動則

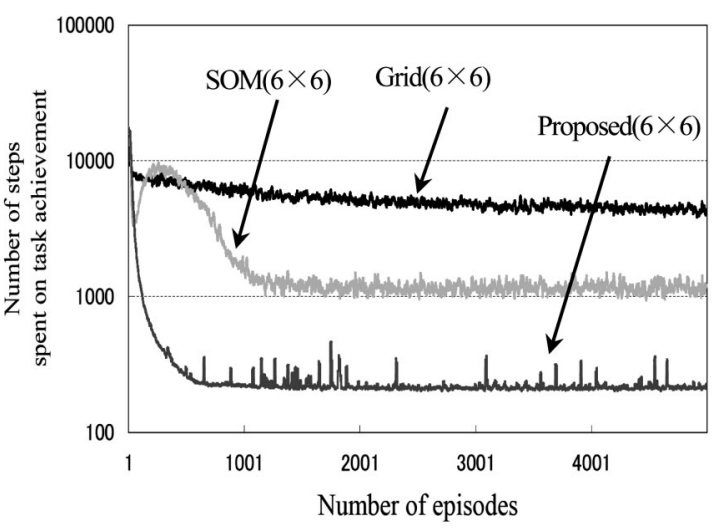

図 7 迷路 1 に打ける学習曲線 （各エピソードにおけるステップ数）

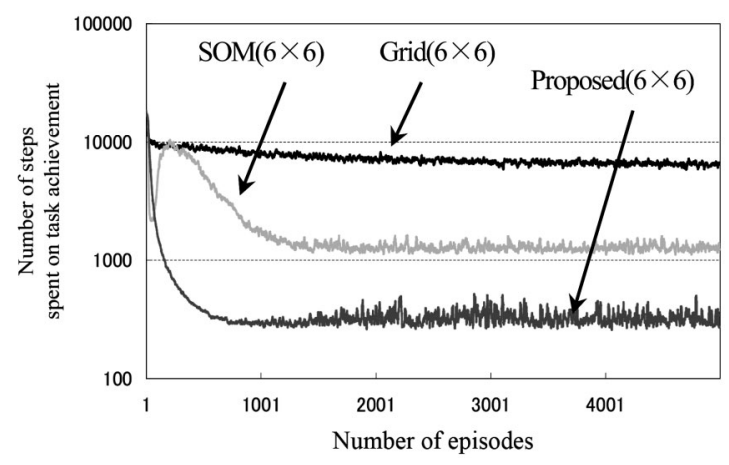

図 8 迷路 2 における学習曲線 (各エピソードにおけるステップ数)

の質もなかなか向上しないが, 提案手法はばらつきが 小さく適切な行動則に収束していることが確認でき る。

またここで注目すべき点は, 通常のSOMでは学習 初期において一度学習が進行しステップ数が減少に向 かうが，その後ステップ数が大幅に増加していること である。このことから，通常のSOMをPSの状態空間 構成に用いると, 学習初期に獲得した行動則とその後 に獲得した行動則の間にズレが生じてしまい, 性能が 悪化することが確認できる。 また，提案手法により， その問題点が回避できたことも確認できる.

\subsection{2 状態空間}

図 9 〜困12は獲得された状態空間，すなわちSOM の発火域を表している。発火域は知覚入力值が取り得 る範囲に対して同一のノードが勝者になる(発火する) 領域を表している。ここでは学習の進行に伴って発火 域が変化していく様子を左上から50エピソード，100 

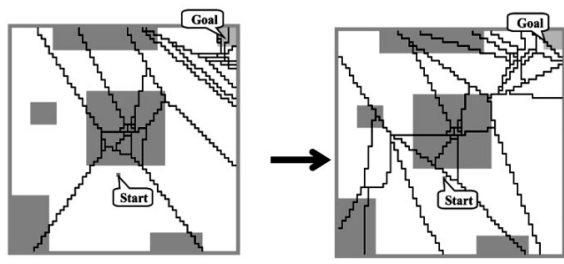

50 エピソード

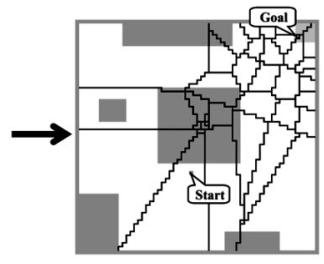

500 エピソード
100 エピソード

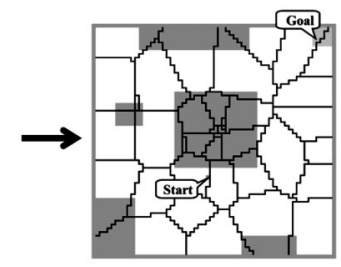

5000 エピソード

図 9 SOM によって構成された状態空間（迷路 1 ）
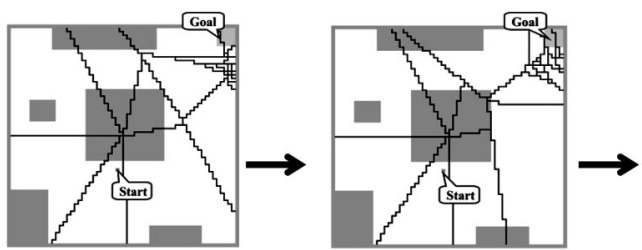

50 エピソード

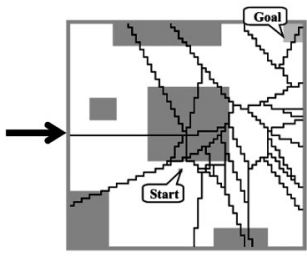

100 エピソード

500 エピソード

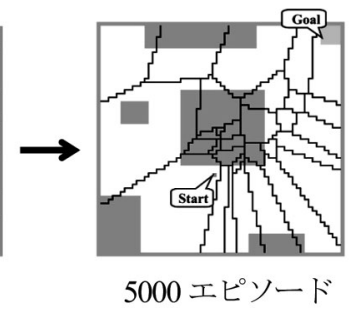

図10 提案手法によって構成された状態空間(迷路 1 )
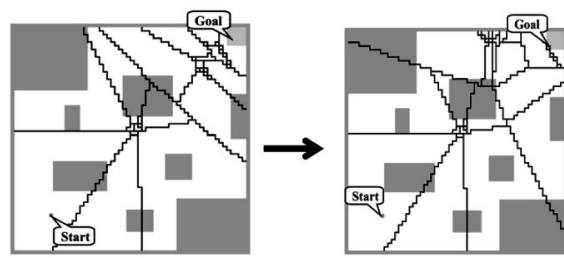

50 エピソード

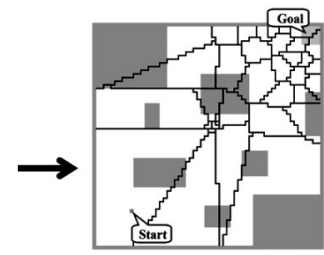

500 エピソード
100 エピソード

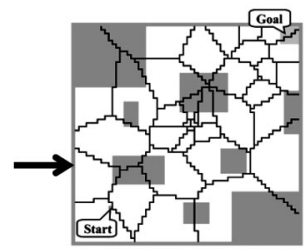

5000 エピソード

図 11 SOM によって構成された状態空間（迷路 2）

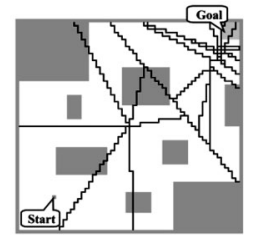

50 エピソード

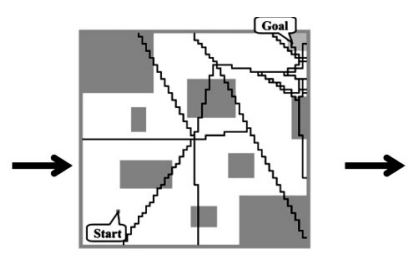

100 エピソード

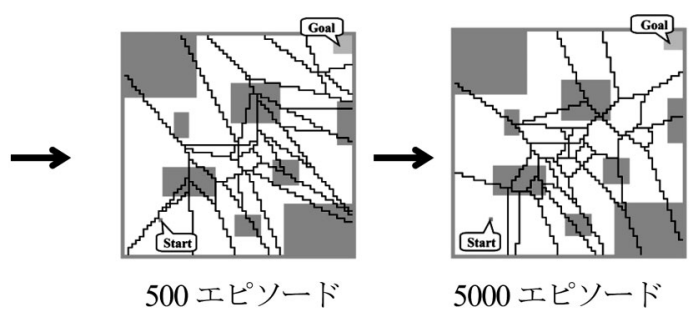

図12 提案手法によって構成された状態空間(迷路 2)

エピソード，500エピソード，5000エピソードの順に 表記した。

最終的に獲得された状態空間(図 9，10および図 11，12）を只れ乤れ比較すると，通常のSOMの状態空 間は各状態の発火域の大きさの差が比較的少なく, ノードの粗密の差が少ない. それに対して提案手法で は，障害物付近などの行動則を獲得しにくい領域や， タスクの達成において重要な領域にノードが優先的に 配置されノード粗密の差が明確になっている。このこ とから提案手法により, 行動則の獲得において適切な ノード配置が出来るようになったことが確認できる.

また, 通常のSOM(図 9 ，11)では50エピソードか ら100エピソードまでの学習初期に扎いて多くのノー ドの発火域が変化している。このことから, 学習初期 に獲得した行動則と実際に取るべき行動の間にズレが 生じてしまったため, 100 エピソードから500エピ ソードあたりにかけて行動則の獲得が妨げられている ことが確認出来る(図 7，8). それに対して提案手法 (図10，12)では，50エピソードから100エピソードに かけてはあまり大きな変化が見られていない．このこ とより, 学習初期では行動則の獲得を妨げるような ノードの更新は回避できていることがわかる.

ゴール付近の領域は報酬獲得に打いて必ず訪問する ためノードの発火頻度が高くなる。このことから， $\mathrm{SOM}$ ・提案手法共に学習初期はゴール付近にノード が多く配置されている. 提案手法と通常のSOMのも う一つの大きな違いは, その後(学習終盤)のノード配 置の変化である. SOMは, 学習終盤にかけてノード は均一に配置されてしまっている(図 9，11)。これ は, SOMは行動則の獲得状況を考慮していないため 適切な行動則が確立されず，いろいろな領域を訪問し 
てしまうためである。それに対して，提案手法では ゴール付近のノードの配置が十分であるときは無駄な ノード配置を避け, 余分なノードは他の学習が進行し ていない領域に引き寄せられる。この性質により，本 提案は学習初期に比較的荒く行動則を獲得し，学習終 盤に詳細な行動則の獲得へと移行していくようにでき ている.

\section{3 考 察}

通常のSOMによる状態空間構成では，マップの形 状が安定しない学習初期に行動則のズレが生じてしま い性能が悪化してしまうだけでなく，マップの形状が お打むね安定してきた学習終盤になっても行動則の質 は向上していない。これは，一度獲得しかけた行動則 に対して異なる行動則が上塗りされるため，行動選択 時に新しい行動則を古い行動則が阻害し，新しい行動 則が選択され難くなってしまったためと考えられる. また, 一度獲得しかけた行動則を壊してから再学習し 直す必要があるため, 新たな行動則の獲得が進行し難 いことも性能悪化の一要因と考えられる。それに対し て, 本提案ではそのような問題は発生せず，良好な結 果が得られた。

また，SOMは近傍が固定されているため学習に関 与しないデッドノードが生じてしまうことがあり, ノードの使用効率が悪い事が問題とされている。実験 ではSOM ・提案手法ともに縦 6 横 6 の合計 36 個の ノードを用意したにもかかわらず発火域を表すと確認 された状態数はいずれの手法においても30前後であっ た。このことより, 発火しないノードは学習に関与し ないデッドノードとなったと考えられる。また， SOM ·提案手法共に図 $9 ， 10$ の障害物内部のような 知覚入力が観測され得ない領域に，ノードが配置され てしまっている。これは, 近傍が固定されているため に障害物を挟んだ領域間で相互干渉が生じ，ノードが 障害物内に引き込まれたと考えられる。このような SOMの近傍が固定されているために生じる問題は, 状態空間構成に打いても同様に生じていまい, 本提案 を用いても回避できなかった。

\section{6. まとめおよび今後の課題}

本稿では, Profit Sharingを実タスクに適用する際 に重要と考えられている状態空間構成問題において競 合学習型のニューラルネットを用いた場合について議 論した。ここでは競合学習型のニューラルネットが PSの学習の立ち上がりの早さに追従するための『相互 学習残参照型近傍関数』を提案し, 計算機実験を通じ てその有効性を検証した。この実験よりSOMを用い
て状態空間構成を行った場合にスムーズに行動則の獲 得が可能となることが確認できた。またこの結果よ り, 通常は環境同定型の強化学習に打いてしか用いら れてこなかった競合学習を行うニューラルネットを PSの状態空間構成に適用できることを示した。

本研究では比較的易しいタスクで有効性の検証を 行った. SOMはマップの位相構造やマップサイズ (ノード数)を事前に決定しておかなくてはならず, タ スクが高度になるとそれらを事前に決定しておくこと は困難である。また，SOMは予めノードを用意して おき, そこから学習するためPSによる更新時に行動 則が上塗りされてしまい, 学習効率が非常に悪い。こ れらの問題は, Growing Neural Gas Network (GNG) [Fritzke95]のようなマップの位相構造を柔軟に変化 させることができ, 必要に応じてノードを追加できる 競合学習型のニューラルネットワークを用いることに よって解決できると考えられる。しかし，GNGは ノード数が恒久的に増加し続けてしまうため予め最大 ノード数を決定して扔かなくてはならない。このこと よりマップサイズに関する問題点は本質的に解決され ているとは言えない。それに対してSelf Organizing Incremental Neural Network (SOINN) [Shen06]は複 雑な知覚入力の分布に対しても適切な状態空間を構成 でき, 必要最小限のノードを追加する事が出来るため SOMの状態空間構成に扔ける問題を解消できると考 えられる。そこで, 今後は本稿において提案した相互 学習残参照型近傍関数を, SOINNに適用した場合に どのような振る舞いをするかを検証していく．また， 今回の提案手法を行動則が獲得出来ていない領域に優 先的にノードを配置するためのノードの追加条件に拡 張していく。そして以上のことを踏まえた上で, 競合 学習型のニューラルネットを用いた内部状態空間構成 に関する議論をさらに深めていく予定である.

\section{謝辞}

本研究はNEDO産業技術研究助成事業から支援を頂 きました。記して感謝致します。

\section{参 考 文 献}

[Asada96] M. Asada, S. Noda, and K. Hosoda. "Actionbased sensorspace categorization for robot learning." In Proc. of IEEE/RSJ International Conference on Intelligent Robots and Systems, pp. 1502- 1509, 1996.

[Yairi00] Takehisa Yairi, Koichi Hori and Shinichi Nakasuka, "Autonomous Reconstruction of State Space for Learning of Robot Behavior,", IEEE/RSJ International Conference on Intelligent Robots and Systems (IROS 2000) , pp.891-896 (2000)

[McCallum95] A.McCallum "Instance-based utile distinc- 
tions for reinforcement learning with hidden state," In proc. of Twelfth International Machine Learning Conference, ML95 (1995)

[Kohonen90] T.Kohonen “The Self-Organizing Map," Proceedings of The IEEE, Vol. 78, No.9, pp.1464-1480 (1990)

[Smith02] A.J.Smith. "Application of the self-organising map to reinforcement learning" Neural Networks Vol.15, pp.1107-1124（2002）

[伊藤 01] 伊藤昭, 金渕満, “知覚情報の粗視化によるマルチ エージェント強化学習の高速化ーハンターゲームを例 に一,”電子情報通信学会論文誌 D - I Vol.J84-D I, No.3, pp.285-293 (2001)

[Moore95] A.W.Moore and C.G.Atkerson "The parti-game algorithm for variable resolution reinforcement learning in multidimensional state-spaces.," Machine Learning, Vol.21, pp.199-233 (1995)

[岩崎 05] 岩崎秀樹, 未田直道 “強化学習における自己組織 化マップを用いた状態空間の自律的構成法,”第 19 回 人工知能学会全国大会論文集，(2005)

[宮崎 99］宮崎和光，木村元，小林重信 “Profit Sharing に基 づく強化学習の理論と応用” 人工知能学会誌 Vol.14, No.5, pp.800-807 (1999)

[宮崎 94] 宮崎和光, 山村雅幸, 小林重信“強化学習におけ る報酬割当ての理論的考察, ”人工知能学会誌 Vol.9, No.4, pp.584- 587 (1994)

[山村 95] 山村雅幸, 宮崎和光, 小林重信 “エージェントの
学習” 人工知能学会誌 Vol.10, No.5, pp.23-29 (1995) [半田 04] 半田久志 “知覚変化予測に基づいた状態分割法を 併用した強化学習”信学技法 NC2004-10, pp.75-79 (2004)

[Fritzke95] B. Fritzke. "A Growing Neural Gas Network Learns Topologies," In Advances in neural information processing systems (NIPS), vol.7, pp.625-632, 1995.

[Shen06] F. Shen , O. Hasegawa. "An incremental network for on- line unsupervised classification and topology learning," Neural Networks, vol.19, no.1, pp.90-106, Jan 2006 .

[Albus95] J.Albus, A.Lacaze and A.Meystel "Multiresolutional Intelligent Controller for Baby Robot," In proceedings of the $10^{\text {th }}$ International Symposium on Intelligent Control (1995)

(2007年 2 月18日 受付)

(2007年12月 3 日 採録)

[問い合わせ先 ]

干 226-8503 神奈川県横浜市緑区長津田町 4259 R2- 52

東京工業大学大学院

総合理工学研究科知能システム科学専攻

斉藤 史哲

TEL : 045-924-5180

FAX : 045-924-5175

E-mail：saitoh.f.aa@m.titech.ac.jp 


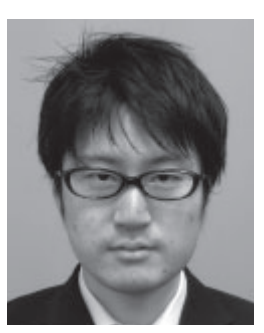

\section{离籐 史哲 [非会員]}

2004年武蔵工業大学工学部経営工 学科卒業. 2006年同大大学院工学研 究科修士課程修了. 現在, 東京工業大 学大学院総合理工学研究科知能システ 厶科学専攻博士課程在学中, 主に機械 学習の研究に従事. 人工知能学会, 口 ボット学会, 電子情報通信学会各学生 会員.

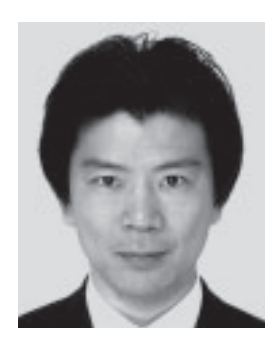

長谷川妿势

1993年東京大学大学院電子工学専 攻博士課程修了, 博士 (工学), 同年電 子技術総合研究所入所, 1999年から 1 年間米国カーネギーメロン大学客員 研究員, 2001年産業技術総合研究所 主任研究員, 2002年東京工業大学像 情報工学研究施設助教授, 画像認識 · 理解, ニューラルネット, パターン認 識, 認知発達ロボティクス等の研究に 従事. 情報処理学会, 日本認知科学 会, 人工知能学会, 日本顔学会, IEEE-CS 等会員.

\section{State Space Construction Method with Self - organizing Map in a Reinforcement Learning System Based on Profit Sharing \\ by}

\section{Fumiaki SAITOH and Osamu HASEGAWA}

\section{Abstract :}

The methodology of state space construction is an important point in the application of reinforcement learning to real tasks. Self-organizing map (SOM) is a useful tool for state space construction. Furthermore, profit sharing (PS) is a practical learning method in a typical class of Partially Observable Markov Decision Processes (POMDPs). However, state space construction by SOM has been used only for Q- learning. In this paper, we present arrangement in a neighborhood function for adaptation of SOM to PS. The effectiveness of the proposed method was verified using a simulation experiment in a maze problem.

Keywords : Self-organizing map, reinforcement learning, profit sharing, neighborhood function, state space construction

\section{Contact Address : Fumiaki SAITOH}

Department of Computational Intelligence and Systems Science Interdisciplinary Graduate School of Science and Engineering, Tokyo Institute of Technology

R2- 52 4259, Nagatuta, Midori-ku, Yokohama, Kanagawa, 226-8503, JAPAN

TEL : 045-924-5180

FAX : 045-924-5175

E-mail : saitoh.f.aa@m.titech.ac.jp 